\title{
Serious Games on Environmental Management
}

Kaveh Madani ${ }^{1}$, Tyler W. Pierce ${ }^{2}$, Ali Mirchi ${ }^{3}$

${ }^{1}$ Centre for Environmental Policy, Imperial College London, London SW7 2AZ, U.K., Tel: +44 (20) 7594-9346, Fax: +44 (20) 7594-9334, Email: k.madani@imperial.ac.uk

${ }^{2}$ Department of Civil, Environmental and Construction Engineering, University of Central Florida, Orlando, FL 32816, U.S.A.

${ }^{3}$ Department of Civil Engineering and Center for Environmental Resource Management, University of Texas at El Paso, 500 W University Ave., El Paso, TX 79968, U.S.A.

\section{ABSTRACT}

Serious environmental management games can improve understanding of practical environmental sustainability challenges by offering opportunities to obtain first-hand experiences that may be otherwise too costly, difficult or dangerous to reproduce in reality. Game-based learning (GBL) has been found to increase soft skills, such as critical thinking, creative problem solving and teamwork, as well as to improve cognitive development, learning retention and social learning, which are important for future environmental researchers and professionals. Environmental management games can be applied in educational settings to promote awareness about sustainable resource planning and management among citizens who are increasingly exposed to products of the information age. This paper provides an overview of game-based learning and the state of serious games (SG) for environmental management, offering insight into their potential as effective tools in facilitating environmental education. SGs have been shown to possess numerous qualities that have been connected with improved learning experiences and cognitive development, but research must continue to study the SGs' efficacy. Shortcomings 
found with games reviewed are that few evaluate or explain pedagogical foundation, and many are hard to implement or not accessible. Methods employed in determining the effectiveness of SGs vary greatly among environmental studies, necessitating a standardized methodology to reduce disparities in testing procedures. Furthermore, a centralized source, effectively an online database for SGs, is needed for locating and obtaining information pertaining to the available environmental games and their most appropriate applications.

\section{KEYWORDS}

Game-based learning; serious games; environmental management; education

\section{Introduction}

Environmental management has long recognized the importance of interdisciplinary collaboration and a systems perspective (Hoekstra 2012; Rusca et al. 2012), providing a suitable context for application of game based learning (GBL). Games can be applied in educational settings to promote awareness about environmental and sustainability challenges among citizens who are increasingly exposed to products of the information age. Computer graphics and realistic simulations allow learners to role-play in environments that would otherwise be difficult to replicate (Kirriemuir and McFarlane 2004). This capability is essential for environmental management education because of the need to make important decisions about "wicked" environmental planning and management problems (e.g., climate change and extreme weather events, ocean acidification, desertification, and biodiversity loss, among others) as opposed to well-defined, end-in-view “tame problems" (Rittel and Webber 1973). 
The youth who were the first generation to grow up with digital technology including internet, computers, video games, MP3 players, and smartphones, have been coined the Netgeneration, Digital-generation or digital natives (Prensky 2001). Prensky (2001) maintains that digital natives think and process information differently than previous generations because of the pervasiveness of exposure to technology that is a key characteristic of today's youth who spend their time differently than former generations. In 2009 , it was estimated that total daily media exposure among American youth ages 8-18 was 10:45 hours on average; an increase from 8:33 hours in 2004 and 7:29 hours in 1999 (Rideout et al. 2010). Video gaming, specifically, increased to an average of 73 minutes per day in 2009, a marked increase from 49 minutes in 2004 and 26 minutes in 1999 (Rideout et al. 2010). This popularity is, in part, because video games provide a practical medium for personal and social gratification as gamers enjoy the challenge of beating the game and other players in an engaging, indiscriminate "level playing field" as compared to the real world (Sherry et al. 2006). The demographic of gamers includes more than just young children and teenage boys. The gender distribution of games is $47 \%$ female and $53 \%$ male and the average age of gamers is 30 years old (Entertainment Software Association 2012).

"Serious games" (SG) developed for educational purposes have experienced increased attention in the past decade (Young et al. 2012) as advances in technology has made electronic media more accessible and digital games more ubiquitous. Areas where SGs are thought to have a particularly high potential for overcoming deficiencies of traditional lecture-driven classes are in science, technology, engineering and math (STEM) curricula (Levine 2011; Mayo 2007). Reasons that students claim to leave STEM programs include either loss of interest in the curriculum, loss of academic self-confidence resulting from a competitive environment 
(Seymour and Hewitt 1997), or incompatible personal learning styles (Bernold et al. 2007). It is suggested that loss of interest in engineering programs may be associated with the dominance of lecture formatted classes (Blickenstaff 2005), which account for more than $95 \%$ of engineering courses (Deshpande and Huang 2011). Mayo (2007) describes five reasons that SGs can improve interest and retention of STEM majors: massive reach, effective learning paradigms, enhanced brain chemistry, increased time on task and better learning outcomes. Implementing games in K12 can also expose students to STEM professions in a manner that is fun and engaging, which could increase recruitment and the retainment of college-bound students in STEM majors.

With so much interest in technology and specifically, gaming, more and more focus outside of the research world is being placed on the potential that games may have as an educational tool. The NMC Horizon Report: 2013 Higher Education was developed to inform education leaders, policy makers, and faculty about new and emerging technology and its potential impact on teaching, learning, and research (Johnson et al. 2013). A key trend noted in the report is the evolution of teaching in higher education to incorporate more informal learning such as online learning, hybrid learning, and collaborative models. Programs such as The National STEM Video Game Challenge promoted by the US government are on the rise. Established by President Obama in 2010, the Video Game Challenge calls for middle and high school students to design STEM related games to promote learner independence (Robertson and Howells 2008), systems thinking, and higher-order skills that are fundamental to STEM learning (Resnick 2012). The US Congress has also launched the E-TECH Caucus for the purpose of educating policymakers and the public about the benefits that the gaming industry can have on education and the economy (Levine 2011). Additionally, in 2012 the first national policy initiative on digital gaming's role in education, health, civic engagement, and numerous other areas was introduced (Toppo 2012). 
This paper provides an overview of GBL and serious environmental management games and their potential to improve cognitive development, professional skills and the learning experience in regard to environmental management. GBL has been found to benefit soft skills such as critical thinking, creative problem solving and teamwork (Johnson et al. 2013; Gee 2004) as well as improve learning retention, cognitive development and socialization, among others (Squire 2008; Kirriemuir and McFarlane 2004; Levine and Vaala 2013; Van Eck 2006). It caters to different learning styles, providing a supplement to the traditional methods in order to accommodate a greater proportion of learning orientations. The review describes the state of SGs in the environmental management field, and provides insight into their variation pertaining to theme, objective, intended participants, game type and availability, among others.

\section{Game-based learning (GBL)}

GBL is a pedagogical method of learning that utilizes role-plays, board games, card games or VGs to promote retention of learned material and cognitive development. For traditional lecture-driven classes, learning occurs in an environment (the classroom) outside the context of the material being taught. On the other hand, the learning environment in a game is relevant to the subject and allows players to apply and practice what they have learned within an authentic context; this style of learning has been shown to be more effective than purely lecture-driven learning (Van Eck 2006). At the foundation of GBL methods are key mechanisms (fundamental aspects) and principles (underlying concepts) that have been identified as important elements for learning (Perrotta et al. 2013). The most commonly supported mechanisms for a successful GBL experience include rules, goals, fictional settings, progressively difficult goals, interactivity and user control, uncertainty, immediate and constructive feedback, situated cognition, and social elements (Perrotta et al. 2013; Annetta 2010; Squire 2008). These elements are implemented 
differently depending on the type of media, e.g. board game versus video game, but follow similar themes nonetheless.

Based on the work of Caillois (1962), Frasca (1999) introduced a classification system in which games are categorized into two groups: paidea and ludus. Ludus games are those that result in winners and losers (e.g. chess or Pac-man) and are more complex. Paidea games, on the other hand, have no true winners or losers (e.g. merry-go-round), providing a different means of GBL that is not driven by competition. The distinction is important because ludus games can create an element of competition, which serves to instill a sense of motivation and drive to perform at a higher level in the game than one's opponent (player or computer). Friendly competition encourages learning material more completely, utilizing critical thinking skills to apply the learned material in a more effective way than other players (Burguillo 2010).

In addition to a paidea and ludus characterization of games as a whole, Frasca (1999) also used this system to classify game rules. Paidea rules establish how the game is played and ludus rules explain how the game is won or lost. For example, in the arcade game Pac-man, paidea rules establish that the player can move up, down, left and right; points are earned by eating Pacdots and a life is lost if Pac-man contacts one of the enemies. The ludus rules for Pac-man determine that a player loses when he runs out of lives and wins when he eats all the Pac-dots and progresses to the next level. In addition to rules, two other elements are used to interact with the player and create the platform where learning occurs. These elements include gameplay and narratives (Ang 2006).

\subsection{Learning principles and orientations}


Learning principles and orientations provide the theoretical foundation as to the efficacy of GBL as a pedagogical tool. Understanding learning principles such as motivation, flow, situated cognition, and socialization help identify game design elements that incorporate specific learning principles which support an intended learning outcome. Motivation or interest in the material being taught plays an important role in learners' initial engagement and affects their intensity and persistence towards learning (Corti, 2006; Dorn 1989; Annetta 2010). Students interested in games will be more likely to spend more time than they would for pencil and paper homework. Jones (2003) surveyed 1162 students from 27 colleges and universities, indicating that $65 \%$ of college students play video, computer or online games regularly or occasionally.

The flow concept explains the optimal experience resulting from the complete immersion of oneself in a challenging environment which produces intrinsic motivation, clear goals, a high degree of control, intent focus and lost awareness of time (Csikszentmihalyi 1991). In respect to video games, flow is the experience of being in "the zone" (Chen 2007), a state of mind common for digital natives and undoubtedly observed by their parents as characteristically involving starring at a TV or computer monitor for hours on end with little regard to their surroundings. Research has shown that the flow state in SGs improves learning (Webster et al. 1993) and is an element that many game developers have tried to incorporate into educational games.

Situated cognition is the ability for students to experience scenarios in a virtual world (for digital games) or role-playing games in the classroom by providing an embodied experience where learning takes place in a contextualized environment. This principle, which finds knowing and doing inseparable, can be used to prepare students for actions that would occur in real-life situations as opposed to learning accomplished in traditional classrooms. Learning occurs through various modalities (words, actions, objects, artifacts, symbols, texts, etc.) in the game's 
environment and receive direct feedback based on the effect of their actions (Gee 2004). Many games also include opportunities for socialization (Levine and Vaala 2013; Van Eck 2006; Squire 2008), normally through the use of teams or as role players addressing different issues. Students playing collaborative games communicate with their peers as they navigate the game, which provides the added benefit of enhancing students' social skills (Kirriemuir and McFarlane 2004).

The most commonly recognized learning orientation models include behaviorism, cognitivism, humanism and constructivism (Smith 1999). Wu et al. (2012) note that constructivism and humanism are emphasized more in game-assisted learning than cognitivism and behaviorism. Behaviorism (Thorndike 1898; Watson 1913; Pavlov 1927) maintains that learning is produced through stimulation and reinforcement and is manifested by a change in behavior (Smith 1999). It is best suited for learning skills that require little cognitive processing such as acquiring factual knowledge, memorizing processes, or developing motor skills (Hense and Mandl 2012). In contrast to behaviorism, cognitivism focuses on an individual's mental process, not only his environment (Smith 1999). Instead of viewing learning as isolated events and actions that occur when our minds passively exchange stimuli with an appropriate response, the cognitive orientation dictates that it is an individual's active mental process that puts the pieces together to gain insight into the solution of a problem (Merriam and Caffarella 1999). Games that support theories of cognitivism typically involve problem-solving by way of a game's narrative (Hense and Mandl 2012). Information embedded into the storyline, the context of the game and the players' own experiences encourage critical thinking as a means of solving complex problems. 
Humanism is focused on the human potential for growth through self-actualization or personal growth and development (Maslow 1970; Rogers 1983), which leads to self-directed learning. Constructivism describes learning as a way to construct meaning from experience (Merriam and Caffarella 1999) and is focused on a holistic perspective of learning which incorporates experience, perception, cognition and behavior (Kolb 1984). Strategy and design games work well for individual-constructivism as do games that use simulations to represent reality (Hense and Mandl 2012). Furthermore, social-constructivism occurs when players communicate and cooperate face-to-face or through online media such as forums, chats, virtual worlds or video/digital messaging (Hense and Mandl 2012).

\subsection{Serious games}

There is a variety of nomenclature utilized for referring to technology or games that are intended for educational or instructional purposes such as e-learning, authentic instruction, alternative purpose games, synthetic learning environments and edutainment, among others. The focus of this paper is on the genre of serious games (SGs). There are numerous definitions for SGs, often varying depending on the different perspectives and purposes that they were developed to explain (Susi et al. 2007). A common theme in most definitions, however, is that SGs are not designed solely for entertainment purposes, but as a tool to educate, train and inform users (Abt 1987; Michael and Chen 2005; Susi et al. 2007). That is not to say that SGs are not entertaining or fun for players, only that entertainment is not the primary focus of such games (Michael and Chen 2005). Some also argue that any entertainment game could be converted to a SG if an educational or training purpose could be developed for the game (Susi et al. 2007), while others contend that the utility of purpose must be present during the development of a game if it is to be considered a SG (Girard et al. 2013). 
SGs that incorporate digital GBL are deemed by many to create the greatest potential for student learning over other media (Prensky 2001; Gee 2004; Squire 2008). The creation of immersive and engaging environments in which players can explore and learn is more feasible than ever with today's technology. By utilizing available technologies in the development of SGs, students will be given the opportunity like never before, to experiment with realistic simulations using animations, graphics and an interactive environments that effectively explain and illustrate course content and develop students' skills (Deshpande and Huang 2011).

Digital SGs have been developed for subjects including health care and medicine (Hansen 2008; Graafland et al. 2012; Patel et al. 2013; Flowers and Agrawal 2014), military training (Losh 2005; McDowell et al. 2006; Smith 2010), computer programming (Muratet et al. 2009 and 2011; Coelho 2011), foreign language and culture (Anderson et al. 2008; Johnson and Wu 2008; Connolly et al. 2011), sustainable resource management (Pierce and Madani 2013 and 2014), business management (Faria et al. 2009; Riedel and Hauge 2011; Parsons et al. 2012), health promotion (Wattanasoontorn et al. 2013), engineering (Mayo 2007; Coller and Scott 2009; Coller and Shernoff 2009; Pierce 2013), mathematics (Chang et al. 2012), and physics (While 1984; Joiner et al. 2013) for the positive impacts that they have been found to support, including analytical and spatial skills, strategic skills and insight, learning and recollection capabilities, psychomotor skills, visual selective attention improved self-monitoring, problem recognition, problem-solving, decision-making, better short-term and long-term memory, and increased social skills (Susi et al. 2007).

There are some drawbacks to digital SGs. Many educators do not have the time or skill to develop games on their own and having them designed by professionals is costly and impractical (Whitton 2012). To compound this issue, educators would be required to spend additional time 
learning the game, developing methods to implement it in the classroom and convincing school stakeholders of its educational benefits, a time-consuming venture some educators might rather forgo (Kirriemuir and McFarlane 2004). Additionally, not all games are designed with wellestablished learning theories in place, leading to players failing to acquire the intended results. Therefore, research into the most effective design models is ongoing (Annetta 2010; Gunter et al. 2006; Kiili, 2005; Sweester and Wyeth 2005; Wilson et al., 2009; Garris et al. 2002) for producing successful learning through SGs.

\section{GBL Literature Review}

One of the first reviews related to GBL was that of Randel et al. (1992) who investigated the effectiveness of games and simulations for educational purposes, separating games and simulations into categories related to a field of interest: social sciences, math, language, arts, physics, biology and logic. Using posttests of games/simulations compared to those of the posttests of traditional teaching techniques, they suggested that $56 \%$ of the reviewed studies showed no difference in students' performance when either teaching method was utilized, $32 \%$ favored games/simulations, $7 \%$ favored games/simulations but had questionable controls, and 5\% favored traditional teaching techniques. Randel et al. (1992) also indicated significant advantage of games/simulations in terms of the students' interest in and retention of the learned material over time, especially when games/simulations had a clearly stated goal (such and math, physics and languages) as opposed to when they were more general (such as social sciences).

Wolfe (1997) reviewed business games that featured three criteria: predefined, objectively measured learning objectives; controlled or equivalent group research designs; and objectively assessed learning outcomes. GBL was found to be advantageous to learning via case studies, the 
preferred method for teaching strategic management. Hays (2005) conducted an extensive review of instructional games with an emphasis on empirical research in order to connect previous literature on the effectiveness of games. The study suggests that empirical research on the effectiveness of games is "fragmented" with literature often focused on different tasks, age groups, and types of games. He affirms that some research reveals games can be effective tools for learning, but asserts that there is no evidence that games are the preferred method of instruction for all situations. Additionally, students' comprehension of intended learning outcomes was found to increase with instructional support by gameplay and the inclusion of feedback mechanisms and a debriefing session upon completion of a game (Hays 2005).

A meta-analysis by Vogel et al. (2006) investigated studies concerning games and interactive simulations that included cognitive gains or attitudinal changes as one of the main hypotheses. The meta-analysis, which only included studies that reported statistics evaluating gaming and interactive simulations against traditional classroom teaching, suggests that application of games or simulations resulted in significantly higher cognitive gains and improved attitudes towards learning than with the use of traditional teaching techniques. Another metaanalysis by Ke (2009) examined both qualitative and quantitative evidence for computer games being used for learning and the factors, if any, that promote the effectiveness of instructional games. Out of the 65 studies, $52 \%$ reported significant positive effects for the use of computerbased games, $26 \%$ reported mixed-results (positively affecting certain learning outcomes, but not others), $18 \%$ reported no difference and only one study reported that conventional instruction was more effective than the corresponding instructional game. Furthermore, it was found that instructional support features are a necessary component of effective games and that the best 
practices for designing and applying instructional games is to align and integrate three clusters of key variables: learning, learner and instructional design (Ke 2009).

Perrotta et al. (2013) synthesized the impact of GBL on students and schools, reporting that while the literature was divided as to the effect that games can have on overall academic achievement, there is a predominant indication of improved problem-solving skills and knowledge acquisition associated with gaming. Concerning the impact that GBL might have on schools, Perrotta et al. (2013) recognized that overall, the results "appear to demonstrate a positive relationship between gaming in the classroom, learning outcomes and motivation and engagement." Most recently, a meta-analysis by Girard et al. (2013) examined the effectiveness of VGs and SGs from 2007-2011 on learning and engagement based on 9 studies containing empirical data from game evaluations, utilizing "pre-test - game - post-test" design and containing a control group. This synthesis reported moderate positive effect on learning, although lack of precise quantitative data hindered evaluation of the magnitude of the learning and improved engagement and motivation. Further, the combination of results achieved, in conjunction with prior literature regarding the effect of engagement, lead them "to think that SGs might be powerful tools for learning." In addition, Girard et al. (2013) concluded that elements of each game such as quality of design, game mechanics, devices used for play, game scenario, integration of additional elements, and context of use will affect the efficacy of a game and should therefore be considered specifically and at an individual level.

\section{Environmental Management Games}

Environmental systems involve complex and interdisciplinary characteristics that not only contribute to the difficulty of their management, but also to the challenge of educating students 
and stakeholders on such matters. This review provides a compilation of environmental management games that can assist educators and researchers locate a tool appropriate for their objective, whether it be education, mediation, negotiation, etc. Research into the potential effects and uses of GBL, especially those that feature learning orientations as their framework bears promise for facilitating teaching and understanding of environmental management concepts. There are a few reviews of games for engineering (e.g. Katsaliaki and Mustafee (2012) who surveyed sustainable development games and Deshpande and Huang (2011) who reviewed simulation games for various areas of engineering), but none for environmental management for higher education students, professionals or stakeholders. This review also details what topics or subject areas have received the most interest and which need further development. It is timely to consider implementing SGs as they continue to gain momentum and improve in terms of pedagogy and usability design. The New Media Consortium (NMC) Horizon Report (2013) expects to see widespread adoption of games and gamification in higher education by 20152016.

\subsection{Dataset}

Games were identified by searching the OneSearch database for keywords including: games, player, education or teaching, in combination with other keywords such as environmental, natural resources, water, water resources, etc. The same process was also repeated on Google and Google Scholar search engines, for which the first 50 results were checked. Information regarding the remaining games was obtained from additional literature search. 
Games were included if they met the following criteria: (1) intended for use in higher education and/or by stakeholders and professionals; (2) met the definition of SG (i.e., games that established hard ludus rules, were not designed solely for entertainment purposes, and were not merely simulation games); and (3) intended for educational or instructional use. Examples of games that were not considered suitable for inclusion were the well-known simulations SimEarth (Wright and Haslam 1990), which teaches global ecology and earth science and SimCity 4 (D'Artista and Hellweger 2007), which can be used for teaching urban hydrology and water management. These games were not included in the survey because they do not establish hard ludus rules and their development was not for educational or instructional use. Similarly, face-toface role-plays such as The Externalities Game, The Environmental Management Game, The Location Game and The Agricultural Policy Game (Bazan 1976) were not discussed in conjunction with this paper as they fail to provide hard ludus rules and are more similar in design to that of a simulation game. As previously stated, addition of ludus rules to a game can effectively transform any paidea game into a ludus game, but for the purposes of this paper, only games containing predefined, hard ludus rules are considered.

Twenty-five SGs were found that met the inclusion criteria necessary to be considered a SG related to environmental management. Table 1 outlines these games chronologically by name and includes a source where information pertaining to each game can be found. The games included in Table 1, range from the Irrigation Management Game, developed in 1994 to the Climate Change Survivor game, created in 2013. Figure 1 shows the number of games that have been developed over this time frame. This figure shows a positive trend in development of environmental management SGs, consistent with the reported expansion of the development of educational games recent history (Prensky 2001; Susi et al. 2007). 
[Insert Table 1]

[Insert Figure 1]

\subsection{Analysis variables}

In order to analyze the 25 environmental management games listed in Table 1, specific information about each game was recorded. Pertinent information was extracted from academic papers, the game's website or by playing the games. The following variables were determined to be of interest:

1. Theme: the main focus of the game, e.g. climate change, water management, ecosystem ecology. Themes are not mutually exclusive;

2. Player's role: the identity of the character that a player assumes in the game, for example, in the Irrigania game (Seibert and Vis 2012) each player acts as a farmer in charge of irrigated crops;

3. Game objective: the specific result that a player aims to achieve by the end of the game;

4. Number of players: identifies the number of players that can participate in the game;

5. Participants: establishes the group of players the game was developed for: students, professionals or stakeholders;

6. Type of game: the classification of each game, whether the game is a board game, card game, digital game (electronic game with a user interface and visual feedback), online digital game (digital game that is played online), and hybrid simulation game (role-play, board game or card game that utilizes a computer simulation to produce results that progress the game); 
7. Graphics: the dimensions of the game's visual display, either 2D or 3D; and

8. Availability: identifies how the game can be obtained.

Table 1 provides an overview of each game including its theme (column 4), player's role (column 5) and game objective (column 6). The number of subjects for the game's theme was kept as small as possible to emphasize the main topic of the game. For example, the chief themes present in the game Citizen Science include lake ecology and conflict resolution, however, other topics are, to a lesser degree, encountered within the game such as wetlands, flooding, and water quality. These secondary subjects are left out of thematic descriptions to provide clarity in the attempt to demonstrate each game's individual niche in environmental management. Table 2 presents additional game information including: number of players, participants, type of game, computer graphics (2D or 3D), and availability of the game.

\section{[Insert Table 2]}

\subsection{Observations}

The most ubiquitous themes of the 25 games comprised conflict resolution (25\%), water management (23\%), irrigation (9\%), ecosystem ecology (8\%) and environmental education $(8 \%)$. Figure 2 displays these results, where the category "other" encompasses themes with only one count (e.g., agricultural and farming management, energy, geology, globalization, risk analysis and silvopasture management).

\section{[Insert Figure 2]}

In the majority of games, player's assumed a role of power position or decision-maker such as a farmer, manager, community leader, or landowner. In these games the player usually has 
complete authority to make decisions that affect a larger group of individuals. In multi-role games (indicative of a multi-player game) the role of the individual players is less powerful and often in conflict with those opposing players. For example, in the Butorstar game (2007) players represent reed harvesters, stockbreeders, naturalists or hunters and each must make choices based on their role, which in turn affects the virtual wetland in the game. Each player can only control specific dynamics related to his role; a reed harvester's job is to maintain or increase the areas of reed harvested and the naturalist is trying to maintain and develop the reedbed as a wildlife refuge, opposing goals resulting in a conflict of interest.

The five styles of game design among the 25 games analyzed included hybrid simulation games $(32 \%)$, online digital games (32\%), board games $(20 \%)$, card games $(12 \%)$ and digital games (4\%). Figure 3 displays the thematic breakdown of environmental management games in the compiled sample. Of the games evaluated, $28 \%$ were single-player, $24 \%$ were multipleplayer games with no specific number of players required, and the remaining games required between 2 and 26 players. It is important to note that many of these games, even the singleplayer games, could be modified for use by teams of players instead of by individuals. For example, although Aqua Republica is a single-player game in which the player's role is that of a city planner, a team of 3-4 students or even an entire class could work together while playing the game.

The majority of the games $(84 \%)$ were intended for a combination of student, professional and stakeholder use, and $16 \%$ were created for the general public. We differentiate between stakeholders and the general public based on their "degree of care" about the games' thematic environmental management problem. Stakeholders are a targeted group of players with personal interest in the environmental management problem because of its direct consequences for them. 
Example of stakeholders is a group of Vietnamese farmers who played SAMBA, a role play game in the context of land use change dynamics, which has direct implications for their livelihood (Boissau et al. 2004). A member of general public, on the other hand, is a player who may not have to personally cope with direct consequences of an environmental problem, e.g. players of Climate Challenge, a free online game in which the user assumes the role of the president of the European Nations, attempting to save the Earth.

\section{[Insert Figure 3]}

The majority of games accessed were 2D; only the Sustainable Delta game (Haasnoot et al. 2010), Fate of the World, and Aqua Republica were 3D. The games labeled "N/A" in the Computer Graphics column in Table 2 consist of those without computer graphics. One of these games is not a traditional board game however; the River Basin Game (Lankford et al. 2004) is a $3 \mathrm{D}$ representation of a watershed constructed of wood. In this game, marbles are used to represent water, which flows down the game board and is captured by offshoots into a farmer's crops. Geology Explorer (Saini-Eidukat et al. 2002) classifies itself as a 2.5-dimensional game, but is technically a 2D game with techniques that make some aspects appear 3D. Other games like Citizen Science (Gaydos and Squire 2012) and Catchment Detox fall within this intermediate classification as well. Concerning availability, $36 \%$ of the games are available for free online, $4 \%$ for purchase online, $16 \%$ provide directions describing play/design of the game, $4 \%$ supply contact information and $36 \%$ do not offer information as to the games availability.

\section{Discussion}

Despite the proliferation of GBL papers in the last two decades, GBL learning is still a burgeoning field, and the dialogue about applications of SGs in environmental management is in 
its inception stage. Herein, we analyzed the compiled sample of SGs according to theme, player's role, game objective, number of players, intended audience, graphics, and availability. Extensive research with contributions from across the field of environmental management is required to rigorously understand important characteristics of SGs such as incorporated learning principles, learning objectives, game strategies, learning effectiveness, communication (e.g., in multi-player games), and learning orientations of the users, among others.

SGs possess the capability to manifest numerous qualities that have been connected with improved learning experiences and cognitive development. This review of environmental management games documented 25 SGs that have been developed between 1994 and 2013. During this time the number of games has continued to increase and although no major trend in the type of game (hybrid simulation, online digital game, digital game, card game or board game) is discernible, hybrid simulations and online digital games appear to be developing with more frequency than the other groups. The games vary considerably encompassing topics from climate change and water management to globalization, risk analysis and conflict resolution. The complexity of the games and the time required for play was also quite disparate. The main shortcomings of the reviewed environmental management games were the omission of: (1) evaluations for assessing a game's effectiveness; and (2) pedagogical foundations for which the game was based upon.

One of the current obstacles for using SGs in higher education is associated with difficulties in seeking out available games. Often proving more of a challenge, it must then be ascertained whether the game is appropriate for one's intended use. The intended learning outcomes or skill development are not always explained thoroughly and many games are not well suited for classroom use. A centralized source for locating and obtaining information 
pertaining to the available educational games and their most appropriate applications, effectively an online database for SGs, would undoubtedly prove helpful for interested educators and students. Such a database could provide links to online games, directions to create a game (card game, board game, or role-play) and methods for implementation. Ideally, such online database would include features allowing users to provide feedback on games, collaboration between SG developers and dissemination of new information in regard to SGs.

Because methods employed in determining the effectiveness of SGs vary greatly among studies, prevention of disparities in testing procedures, such as among the control groups, necessitates development of standardized methods for evaluating the effectiveness of SGs. The GBL literature is not conclusive about the effectiveness of GBL learning. It is widely acknowledged that measuring "true learning" is difficult and evaluations often boil down to a set of test scores that may not reflect deep understanding of the subject matter (Prensky 2005). While evidence has been found about the effectiveness and efficiency of serious video games for language learning, history, and physical education (Young et al. 2012), various styles of game design (e.g., hybrid simulation games, online digital games, board games, card games, and digital games) have not been collectively assessed with respect to their effectiveness and efficiency to facilitate environmental management education. Developing standardized methods for evaluating the effectiveness of games is a critical research frontier, recognizing that the effectiveness of games is not universal for all educational purposes, and it depends on the design and components of each game and the context in which they are used. Thus, comprehensive assessments of GBL effectiveness should explore game design features, including game mechanics and elements of game narrative and environment. 
Another problem facing the inventory of natural resource games and an impediment to the implementation of GBL is that a majority are not available for free online, making it more burdensome for educators to implement these games in their classrooms and even more unlikely that students would play on their own. Purchasing commercial games and the necessary hardware required to run them, in addition to the time spent by educators to learn the skills essential for game development and application all create added cost burdens to an educational system. To overcome this issue instructors can create low-cost games, teach from games as opposed to with games (using off-the-shelf games) and empower students to learn through creating games (Whitton 2012; Van Eck 2006).

A limitation of this review stems from the fact that there are many games that are not published in academic journals or even available online. The majority of SGs in environmental management disciplines have been created by academics for their own use as teaching tools and are not necessarily made publically available. Beside educational purposes, environmental management games can be used for facilitating environmental negotiation and mediation processes, motivating cooperation among stakeholders on management of environmental resources (Pierce and Madani 2013), and for collecting behavioral data for validation of agentbased and game theoretic environmental models (Pierce and Madani 2014). While review of these functionalities of environmental management games was not intended here, these subjects are worthy of consideration by future studies.

As technology, computing power and computer graphics continue to advance and increasingly become a part of everyday life, particularly in the STEM disciplines, educators should embrace the tools that accompany this technological advance. By improving game design and implementation based on learning principles (e.g., motivation, flow, situated cognition, and 
socialization) and learning orientations (e.g., behaviorism, cognitivism, humanism and constructivism), future SGs can be expanded to improve areas such as cognitive development, acquisition of factual knowledge, teamwork skills, critical thinking skills, and creative problem solving, among others.

\section{Final Remarks}

The purpose of the review was to determine the state of GBL and SGs for environmental management, provide insight into their potential as educational tools in higher education and identify areas of improvement. A number of conclusions can be derived from the described reviews of the GBL literature: (1) the effectiveness of games is not universal for educational purposes, it depends on the design and components of each game; (2) many studies of educational games contain methodological problems and lack quantitative results, making it difficult to assess the accuracy of the findings; (3) there is a need to investigate longitudinal studies to determine the influence, if any, on the effectiveness of games; (4) debriefing is an important element of GBL, allowing participants time to reflect over their experiences and understand the connections between gameplay and instructional objectives; and (5) GBL can increase motivation and engagement, which has beneficial effects on learning outcomes.

Taking into account daily hours spent online by today's learners, there is a great potential to incorporate this style of learning to reach and connect many learners of environmental management concepts. The reviewed games cover a range of learning principles (e.g., motivation, flow, situated cognition, and socialization) and learning orientations (e.g., behaviorism, cognitivism, humanism and constructivism). The multiple learning theories (e.g., experiential and self-directed learning) that arise from different learning principles and 
orientations are of great importance to the notion of GBL as they encompass the principles behind "how" and "why" SGs can teach what they are intended to teach. If games with worthwhile learning objectives are knowledgably designed in which students enjoy participation, the time spent learning could significantly increase. It would require very strong evidence to consider replacement of traditional learning styles with a game-based approach. For now, application of games as a supplement to current practices is more feasible until more conclusive research investigating the relationship between SGs and academic achievement is available and incompatibilities between informal learning and formal practices are overcome.

\section{ACKNOWLEDGMENTS}

The authors thank Kippy Ahluwalia and Summer Carlson from the Hydro-Environmental and Energy Systems Analysis (HEESA) Research Group for their assistance in researching games for this paper. Partial financial support by the U.S. National Science Foundation (NSF grant number 0942242) is also appreciated. Valuable comments and suggestions from four anonymous reviewers are gratefully acknowledged. All opinions, findings, conclusions, and recommendations expressed in this material are solely those of the authors.

\section{REFERENCES}

Abt CC (1987) Serious games. University Press of America, Lanham, MD

Ang CS (2006) Rules, gameplay, and narratives in video games. Simulat Gaming 37: 306-325. doi: $10.1177 / 1046878105285604$

Anderson TAF, Reynolds BL, Yeh XP, Huang GZ (2008) Video Games in the English as a Foreign Language Classroom. In: 2nd IEEE International Conference on Digital Games and Intelligent Toys Based Education, IEEE Press, Banff, pp 188-192 
Annetta LA (2010) The "I's" have it: A framework for serious educational game design. Rev Gen Psychol 14(2): 105-112. doi.org/10.1037/a0018985

Bazan, E J (1976). Environmental simulation games. J Environ Educ 8(2): 41-51. doi:10.1080/00958964.1976.9941564

Bernold, LE, Spurlin, JE, Anson, CM (2007) Understanding our students: A longitudinal-study of success and failure in engineering with implications for increased retention. J Eng Educ 96(3): 263-274. doi:10.1002/j.2168-9830.2007.tb00935.x

Blickenstaff, JC (2005) Women and science careers: Leaky pipeline or gender filter? Gender Educ 17(4): 369-386. doi: 10.1080/09540250500145072

Boissau, S, Anh, HL, Castella, JC (2004) The Samba role play game in northern Vietnam: An innovative approach to participatory natural resource management. Mt Res Dev 24(2): 101-105.

Bots, P. W., \& Hermans, L. M. (2003). Developing 'playable metagames' for participatory stakeholder analysis. Proceedings of the 34th Conference of the International Simulation and Gaming Association (ISAGA) (pp. 647-657). Chiba, Japan: Japan Association of Simulation and Gaming. doi:http://dx.doi.org/10.1659/0276-4741(2004)024[0101:TSRPGI]2.0.CO;2

Burguillo, JC (2010) Using game theory and competition-based learning to stimulate student motivation and performance. Comput Educ 55: 266-575. doi:10.1016/j.compedu.2010.02.018

Burton, MA (1994). The Irrigation Management Game: A role playing exercise for training in irrigation management. Irrig Drain Syst 7: 305-318. doi:10.1007/BF00881557

Caillois, R (1962) Man, play and games. Thames and Hudson, London, p 12. 
Chang, KE, Wu, LJ, Weng, SE, Sung, YT (2012) Embedding game-based problem-solving phase into problem-posing system for mathematics learning. Comput Educ 58 (2): 775-786. doi:10.1016/j.compedu.2011.10.002

Chen, J (2007) Flow in games (and everything else). Communications of the ACM 50(4): 3134.doi: $10.1145 / 1232743.1232769$

Coelho, A, Kato, E, Xavier, J, Gonçlaves, R (2011) Serious game for introductory programming. Lect Notes Comput Sc 6944: 61-71. doi:10.1007/978-3-642-23834-5_6

Coller, BD, Scott, MJ (2009) Effectiveness of using a video game to teach a course in mechanical engineering. Comput Educ 53 (3): pp 900-912. doi:10.1016/j.compedu.2009.05.012

Coller, B, Shernoff, D (2009) Video game-based education in mechanical engineering: A look at student engagement. Int J of Eng Educ 25 (2): 308-317.

Corti, K (2006) Game-based learning; a serious business application. Informe de Pixel Learning 34(6): 1-20.

Csikszentmihalyi, M (1991) Flow: The psychology of optimal experience. Harper Perennial, New York.

Connolly, TM, Stansfield, M, Hainey, T (2011) An alternate reality game for language learning: ARGuing for multilingual. Comput Educ 57 (1): pp. 1389-1415. doi:10.1016/j.compedu.2011.01.009

D'Artista, BR, Hellweger, FL (2007) Urban hydrology in a computer game? Environ Modell Softw 22: 1679-1684. doi:10.1016/j.envsoft.2006.09.004 
Depigny, S, Michelin, Y (2007) SHRUB BATTLE: Understanding the making of landscape. Simulat Gam 38: 263-277. doi: 10.1177/1046878107300666

Deshpande, AA, Huang, SH (2011) Simulation games in engineering education: A state-of-theart review. Comput Appl Eng Educ 19(3): 399-410. doi: 10.1002/cae.20323

DFC Intelligence (2013) Worldwide market forecasts for the video game and interactive entertainment industry.

Dorn, DS (1989) Simulation games: One more tool on the pedagogical shelf. Teach Sociol 17(1): 1-18.

Dray, A, Perez, P, Jones, N, Le Page, C, D'Aquino, P, White, I, Auatabu, T (2006) The AtollGame experience: from knowledge engineering to a computer-assisted role playing game. JASSS 9(1). http://jasss.soc.surrey.ac.uk/9/1/6.html

Entertainment Software Association. (2012). 2012 Sales, demographics, and usage data: Essential facts about the computer and video game industry. Retrieved from http://www.theesa.com/wp-content/uploads/2014/10/ESA_EF_2014.pdf

Etienne, M (2003) SYLVOPAST: A multiple target role-playing game to assess negotiation processes in slyvopastoral management planning. JASSS 6(2).

Faria, AJ, Hutchison, D, Wellington, WJ, Gold S (2009) Developments in business gaming: a review of the past 40 years. Simulat Gam 40: 464-487. doi: 10.1177/1046878108327585 
Flowers, M, G, Aggrawal, R (2014) Second Life ${ }^{\text {TM: }}$ A novel simulation platform for the training of surgical residents. Expert Rev Med Devic 11(2): 101-103.

doi:10.1586/17434440.2014.863706

Frasca, G (1999) Ludology meets narratolotgy: Similitude and differences between (video) games and narrative. Retrieved from Ludology.org.

Garris, R, Ahlers, R, Driskell, JE (2002) Games, motivation, and learning: A research and practice model. Simulat Gam 33: 441-467. doi: 10.1177/1046878102238607

Gaydos, MJ, Squire, K (2012) Role playing games for scientific citizenship. Cult Stud Sci Educ 7: 821-844. doi: 10.1007/s11422-012-9414-2

Gee, JP (2004) What video games have to teach us about learning and literacy. Palgrave Macmillan, New York.

Girard, C, Ecalle, J, Magnan, A (2013) Serious games as new educational tools: how effective are they? A meta-analysis of recent studies. J Comput Assis Lear 29: 207-219. doi: 10.1111/j.1365-2729.2012.00489.x

Graafland, M, Schraagen J, M, MP Schijven (2012). Systematic review of serious games for medical education and surgical skills training. Brit J Surg 99:1322-1330. doi: 10.1002/bjs.8819

Gunter, GA, Kenny, RF, Vick, EH (2006) A case for a formal design paradigm for serious games. Journal of the International Digital Media and Arts Association 3(1): 93-105. 
Haasnoot, M, Offermans, A, van Lieshout, M, Valkeringen, P (2010) Preparing for an uncertain future. In: Pijnappels, M, de Pater, F, van Steenis, O (ed), Deltas in Times of Climate Change. Rotterdam, the Netherlands, p 91.

Hansen MM. (2008). Versatile, immersive, creative and dynamic virtual 3-D healthcare learning environments: a review of the literature. Journal of Medical Internet Research; 10: e26.

Hays, R. T. (2005). The effectiveness of instructional games: A literature review and discussion. Orlando, FL: Naval Air Warfare Center Training Systems Center.

Hense, J., \& Mandl, H. (2012). Learning in or with games? Quality criteria for digital learning games from the perspectives of learning, emotion, and motivation theory. IADIS International Conference on Cognition and Exploratory Learning in Digital Age.

Hirose, Y., Sugiura, J., \& Shimomoto, K. (2004). Industiral waste management simulation game and its educational effect. Journal of Material Cycles and Waste Management, 6, 58-63.

Hoekstra, A. Y. (2012). Computer-supported games and role plays in teaching water management. Hydrology and Earth Systems Sciencs, 2885-2994.

Johnson, L., Becker, S., Cummins, M., Estrada, V., Freeman, A., \& Lundgate, H. (2013). NMC Horizon Report: 2013 Higher Education Edition. Austin, Texas: The New Media Consortium.

Johnson, W. L., \& Wu, S. (April 2008). Assessing aptitude for learning with a serious game for foreign language and culture. In: Proceedings of the ninth international conference on intelligent tutoring systems. Montreal. 
Joiner, R., Iacovides, I., Darling, J., Diament, A., Drew, B., Duddley, J., Owen, M., \& Gavin, C. (2013). Racing academy: A case study of a digital game for supporting students learning of physics and engineering, Cases on Digital Game-Based Learning: Methods, Models, and Strategies, pp. 509-523.

Jones, S. (2003). Let the games begin: Gaming technology and entertainment amon college students. Pew Internet and American Life Project.

Katsaliaki, K., \& Mustafee, N. (2012). A survey of serious games on sustainable development. Proceedings of the 2012 Winter (pp. 1-13). IEEE.

Ke, F. (2009). A qualitative meta-analysis of computer games as learning tools.

Kiili, K. (2005). Digital game-based learning: Towards an experiential gaming model. Internet and Higher Education, 8, 13-24.

Kirriemuir, J., \& McFarlane, A. (2004). Literature review in games and learning.

Kolb, D. A. (1984). Experiential learning: Experience as the source of learning and development (Vol. 1). Englewood Cliffs, NJ: Prentice-Hall.

Lankford, B., Sokile, C., Yawson, D., \& Levite, H. (2004). The river basin game: A water dialogue tool. IWMI.

Levine, M. H. (2011, March 11). Congress launches caucus for competitiveness in entertainment technology. Retrieved from www.joanganzcooneycenter.org/cooney-center-blog127.html. 
Levine, M. H., \& Vaala, S. E. (2013). Games for learning: Vast wasteland or a digital promise? In F. C. Blumberg, New Directions for Child and Adolescent Development, no. 139 (pp. 71-82). Wiley Periodicals, Inc.

Losh, E. (2005). In country with tactical Iraqi: Trust, identity, and language learning in a military video game digital experience. In Proceedings of the Digital Arts and Culture Conference, 69-78.

McDowell, P., Darken, R., Sullivan, J. \& Johnson, E. (2006). Delta3D: a complete open source game and simulation engine for building military training systems. Journal of Defence Modelling and Simulation: Applications, Methodology, Technology, 3 (3), pp. 143-154.

Maslow, A. (1970). Motivation and personality. New York: Harper \& Row.

Mathevet, R., Le Page, C., Etienne, M., Lefebvre, G., Poulin, B., Gigot, G., Mauchamp, A. (2007). BUTORSTAR: A role-playing game for collective awareness of wise reedbed use. Simulation and Gaming, 38(2), 233-263.

Mayo, M. J. (2007). Games for science and engineering education. Communications of the ACM, 50(7), 30-35.

Merriam, S. B., \& Caffarella, R. S. (1999). Learning in adulthood: A comprehensive guide (2nd ed.). San Francisco, CA: Jossey-Bass Publishers.

Michael, D. R., \& Chen, S. L. (2005). Serious games: Games that educate, train, and inform. Muska \& Lipman/Premier-Trade. 
Muratet, M. M., Torguet, P. P., Viallet, F. F. \& Jessel, J. P. (2011). Experimental feedback on prog\&play: a serious game for programming practice. Computer Graphics Forum, 30, 1, 61-73.

Muratet, M., Torguet, P., Jessel, J.-P., \& Viallet F. (2009). Towards a serious game to help students learn computer programming. International Journal of Computerised Games Technology, 1-12.

Parsons, D., Petrova, K., \$ Hokyoung, R. (2012). Mobile Gaming - A Serious Business! In: 7th International Conference on Wireless, Mobile and Ubiquitous Technology in Education, pp. 1724.

Patel, V., Aggarwal. R., Cohen, D., Taylor, D., Darzi, A. (2013). Implementation of an interactive virtual-world simulation for structured surgeon assessment of clinical scenarios. Journal of American College of Surgeons 217, 270-279 (2013).

Pavlov, I. (1927). Conditioned reflexes. New York, NY: Oxford University Press.

Perrotta, C., Featherstone, G., Aston, H., \& Houghton, E. (2013). Game-based learning: Latest evidence and future directions. NFER Research Programme: Innovation in Education. Slough: NFER.

Pierce T. W. (2013). Virtual interactions with real-agents for sustainable natural resource management. M.Sc. Thesis, Department of Civil, Environmental and Construction Engineering, University of Central Florida, Orlando, FL.

Pierce, T., \& Madani, K. (2013). Online gaming for sustainable common-pool resource management and tragedy of the commons prevention. Proceedings of the 2013 IEEE 
International Conference on Systems, Man, and Cybernetics (SMC), pp. 1765 - 1770, Manchester, IEEE, doi: 10.1109/SMC.2013.304

Pierce, T., \& Madani, K. (2014). Online gaming for understanding agents' behavior in watersharing problems. Proceedings of the 2014 World Environmental and Water Resources Congress, pp. 867-1875, Portland, ASCE, doi: 10.1061/9780784413548.187

Prensky, M. (2001). Digital natives, digital immigrants part 1. On the horizon, 9(5), 1-6.

Prensky, M. (2005). Computer games and learning: Digital game-based learning, in Raessens, J., Goldstein, J. (Eds.), Handbook of computer game studies, The MIT Press, Cambridge, MA, pp. $97-123$.

Randel, J. M., Morris, B. A., Wetzel, C. D., \& Whitehill, B. V. (1992, September). The effectiveness of games for educational purposes: A review of recent research. Simulation \& Gaming, 23(261). doi:10.1177/1046878192233001

Resnick, M. (2012). Mother's Day, Warrior Cats, and Digital Fluency: Stories from the Scratch Online Community. Proceedings of the Constructionism 2012 Conference. Athens, Greece.

Rideout, V. J., Foehr, U. G., \& Roberts, D. F. (2010). Generation $\mathrm{M}^{\wedge} 2$ : Media in the lives of 8to 18- year olds. Henry J. Kaiser Family Foundation. Menlo Park, California: Henry J. Kaiser Family Foundation.

Riedel J, Hauge J (2011) State of the art of serious games for business and industry. In: 17th International Conference on Concurrent Enterprising (ICE), pp 1-8. 
Rittel HW, Webber MM (1973) Dilemmas in a general theory of planning. Policy Sciences, $4(2), 155-169$.

Robertson, J., \& Howells, C. (2008). Computer game design: Opportunities for successful learning. Computers \& Education, 50(2), 559-578.

Rogers, C. R. (1983). Freedom to learn for the 80's (Vol. 40). Columbus, OH: Merrill.

Rusca, M., Huen, J., \& Schwartz, K. (2012). Water management simulation games and the construction of knowledge. Hydrology and Earth Systems Sciences, 2749-2757.

Saini-Eidukat, B., Schwert, D. P., \& Slator, B. M. (2002). Geology explorer: Virtual geologic mapping and interpretation. Computers and Geosciences, 1167-1176.

Seibert, J, Vis, MJ (2012) Irrigania - a web-basd game about sharing water resources. Hydrol and Earth Syst Sci 16: 243-262. doi: 10.5194/hess-16-2523-2012

Seymour, E, Hewitt, NM (1997) Talking about leaving: Why undergraduates leave the sciences.Westview Press, Boulder, CO.

Sherry, JL, Lucas, K, Greenberg, BS, Lachlan, K (2006) Video game uses and gratifications as predictors of use and game preference. In Vorderer, P, Bryant, J (eds), Playing computer games: Motives, responses, and consequences. Mahwah, Erlbaum, pp 213-224.

Smith, M. K. (1999). Learning Theory. The encyclopedia of informal education.

Smith, R (2010) The long history of gaming in military training. Simulat Gam 41(1): 6-19. doi: $10.1177 / 1046878109334330$ 
Squire, KD (2008) Video game-based learning: An emerging paradigm for instruction.

Performance Improvement Quarterly 21(2), 7-36. doi:10.1002/piq.20020

Susi, T, Johannesson, M, Backlund, P (2007) Serious games - An overview.

Sweester, P, Wyeth, P (2005) GameFlow: A model for evaluating player enjoyment in games. Computers in Entertainment 3(3). 10.1145/1077246.1077253

Thorndike, EL (1898) Animal intelligence: An experimental study of the associative processes in animals. PSYCHOL MONOGR-GEN A 2(4): i-109. doi:http://dx.doi.org/10.1037/h0092987

Toppo, G (2012, 2 2). White House office studies benefits of video games. USA Today.

Torres, M, Macedo, J (2000) Learning Sustainable Development with a New Simulation Game. Simulat Gam 31(1): 119-126. doi: 10.1177/104687810003100112

Van Eck, R (2006) Digital game-based learning: It's not just the digital natives that are restless. EDUCAUSE Rev 41(2): 1-16.

Vogel, JJ, Vogel, DS, Cannon-Bowers, J, Bowers, CA, Muse, K, Wright, M (2006) Computer gaming and interactive simulations for learning: A meta-analysis. J Educ Comput Res 34(3): 229-243. doi: 10.2190/FLHV-K4WA-WPVQ-H0YM

Watson, JB (1913) Psychology as the behaviorists views it. Psychol Rev 20(2): 158-177. doi: http://dx.doi.org/10.1037/h0074428

Wattanasoontorn, V, Boada, I, García, R, Sbert, M (2013) Serious games for health. Entertainment Computing 4(4): 231-247. 
Webster, J, Trevino, LK, Ryan, L (1993) The dimensionality and correlates of flow in humancomputer interactions. Comput Hum Behav 9(4), 411-426.doi: 10.1016/0747-5632(93)90032-N

White, BY (1984) Designing computer games to help physics students understand Newton's laws of motion. Cognition Instruct 1(1), 69-108. doi: 10.1207/s1532690xci0101_4

Whitton, N. (2012). The place of game-based learning in an age of austerity. Electronic Journal of e-Learning, 10(2), 249-256. Retrieved from www.ejel.org

Wilson, KA, Bedwell, WL, Lazzara, EH, Eduardo Salas, CS, Estock, JL, Orvis, KL, Conkey, C (2009) Relationships between game attributes and learning outcomes: Review and research proposals. Simulat Gam 40(2), 217-266.

Wolfe, J (1997) The effectiveness of business games in strategic management coursework. Simulat Gam 28(360): 360-376. doi:10.1177/1046878197284003

Wright, W., \& Haslam, F. (1990). SimEarth: The living planet. Moraga, CA: Maxis.

Wu, WH, Chiou, WB, Kao, HY., Hu, CHH, Huang, SH (2012) Re-exploring game-assisted learning research: The perspective of learning theoretical bases. Comput Educ 59: 1153-1161. doi:10.1016/j.compedu.2012.05.003

Young, MF, Slota, S, Cutter, AB, Jalette, G, Mullin, G, Lai, B, Yukhymenko, M (2012) Our princess is in another castle: A review of trends in serious gaming for education. Rev Educ Res 82(1): 61-89. doi: 10.3102/0034654312436980 
List of Tables

Table 1. Serious environmental management games.

Table 2. Additional information on the reviewed environmental management games. 
Table 1. Serious environmental management games.

\begin{tabular}{|c|c|c|c|c|c|}
\hline Year & Game name & Source & Theme & Player's role & Game objective \\
\hline 1994 & $\begin{array}{c}\text { Irrigation } \\
\text { Management Game }\end{array}$ & Burton (1994) & $\begin{array}{l}\text { Irrigation, water management, } \\
\text { conflict resolution }\end{array}$ & $\begin{array}{l}\text { Irrigation agency staff, } \\
\text { farmer }\end{array}$ & $\begin{array}{l}\text { Develop understanding of issues involved in managing an irrigation system } \\
\text { and the importance of communication to the system performance. }\end{array}$ \\
\hline 1998 & Geology Explorer & $\begin{array}{l}\text { oit.cs.ndsu.nodak.edu/ } \\
\text { menu/ } \\
\text { Saini-Eidukat et al. } \\
(2002)\end{array}$ & Geology & Geologist & $\begin{array}{l}\text { Travel to a newly discovered Earth-like planet on an expedition to locate a } \\
\text { particular mineral and map a metamorphic terrain. }\end{array}$ \\
\hline 1999 & Build a Prairie & $\begin{array}{l}\text { bellmuseum.umn.edu/ } \\
\text { games/prairie/build/tb1 } \\
\text {.html }\end{array}$ & $\begin{array}{l}\text { Environmental management, } \\
\text { ecology }\end{array}$ & Ecosystem restorer & $\begin{array}{l}\text { Restore a threatened prairie to its natural state by selecting the appropriate } \\
\text { plants and animals to be returned to the land. }\end{array}$ \\
\hline \multirow{3}{*}{2000} & $\begin{array}{l}\text { Learning Sustainable } \\
\text { Development Game }\end{array}$ & $\begin{array}{c}\text { Torres and Macedo } \\
(2000)\end{array}$ & Sustainable development & Community representative & $\begin{array}{l}\text { Promote awareness and explore attitudes toward environmental conservation } \\
\text { and urban development. }\end{array}$ \\
\hline & Samba Role Play & Boissau et al. (2004) & Environmental management & Farmer & $\begin{array}{l}\text { To allocate land, labor and capital in order to grow rice, clear forests, plant } \\
\text { cash crops, purchase animals, etc. to be able to provide for your family and pay } \\
\text { workforce. }\end{array}$ \\
\hline & $\begin{array}{l}\text { The Great Green } \\
\text { Web Game }\end{array}$ & $\begin{array}{l}\text { web.cs.wpi.edu/ clayp } \\
\text { ool/iqp/green/ }\end{array}$ & $\begin{array}{l}\text { Environmental education, } \\
\text { energy use }\end{array}$ & Yourself & To test your knowledge on how consumer choices affect the environment. \\
\hline \multirow[t]{2}{*}{2003} & $\begin{array}{l}\text { Industrial Chlorine } \\
\text { Transport Metagame }\end{array}$ & $\begin{array}{l}\text { Bots and Hermans } \\
\quad(2003)\end{array}$ & $\begin{array}{l}\text { Risk analysis, environmental } \\
\text { impact analysis }\end{array}$ & $\begin{array}{l}\text { Polymer company, chlorine } \\
\text { gas company, railroad } \\
\text { company, government, } \\
\text { citizens }\end{array}$ & $\begin{array}{l}\text { Role players must negotiate and make decisions based on their interests in } \\
\text { regards to an industrial chlorine transportation company that wishes to increase } \\
\text { its production. }\end{array}$ \\
\hline & Slyvopast & Etienne (2003) & $\begin{array}{l}\text { Silvopasture management, } \\
\text { conflict resolution }\end{array}$ & Shepherd, forester & $\begin{array}{l}\text { Promote awareness of the difficulties in silvopasture management plan } \\
\text { negotiations between forestry practitioners and herdsmen. }\end{array}$ \\
\hline \multirow[t]{2}{*}{2004} & River Basin Game & Lankford et al. (2004) & $\begin{array}{l}\text { Irrigation, water management, } \\
\text { common pool resources, } \\
\text { conflict resolution }\end{array}$ & Farmer & $\begin{array}{l}\text { Players controlling different sections of a river basin and try to manage wate } \\
\text { use for farming under different scenarios. Promotes understanding of a } \\
\text { catchment, factors controlling access to water, conflict dynamics and allows } \\
\text { participants to react to different scenarios. }\end{array}$ \\
\hline & $\begin{array}{l}\text { Industrial Waste } \\
\text { Game }\end{array}$ & Hirose et al. (2004) & Environmental education & Industrial plant manager & $\begin{array}{l}\text { Develop an understanding of and solutions for the social dilemma between } \\
\text { individual interest of hazardous dumping and the social cost it creates. }\end{array}$ \\
\hline \multirow{2}{*}{2006} & Shrub Battle & $\begin{array}{l}\text { Depigny and Michelin } \\
\text { (2007) }\end{array}$ & $\begin{array}{l}\text { Agricultural management, } \\
\text { farming systems, conflict } \\
\text { resolution }\end{array}$ & Farmer, plants & $\begin{array}{l}\text { To help make future rural planners aware of the complex relationships between } \\
\text { landscape dynamics and agricultural practices in farming systems. }\end{array}$ \\
\hline & Climate Challenge & $\begin{array}{l}\text { bbc.co.uk } / \text { sn } / \text { hottopics/ } \\
\text { climatechange/climate } \\
\text { challenge }\end{array}$ & Climate change & $\begin{array}{l}\text { President of the European } \\
\text { Nations }\end{array}$ & $\begin{array}{l}\text { Make decisions to confront global climate change at home and abroad while } \\
\text { maintaining political support, protecting the environmental and improving the } \\
\text { economy. }\end{array}$ \\
\hline 2007 & Butorstar & Mathevet et al. (2007) & $\begin{array}{l}\text { Environmental management, } \\
\text { water management, ecology, } \\
\text { conflict resolution }\end{array}$ & $\begin{array}{l}\text { Reed harvester, } \\
\text { stockbreeder, naturalist, } \\
\text { hunter }\end{array}$ & $\begin{array}{l}\text { Promote awareness of (1) biological and hydrological interdependencies and } \\
\text { their dynamics on different spatial and temporal scales; (b) the technical and } \\
\text { socioeconomic factors involved in different types of reedbed use; (c) the } \\
\text { usefulness of negotiation for establishing collective management rules. }\end{array}$ \\
\hline
\end{tabular}




\begin{tabular}{|c|c|c|c|c|c|}
\hline Year & Game name & Source & Theme & Player's role & Game objective \\
\hline & Atoll Game & Dray et al. (2006) & $\begin{array}{l}\text { Water management, conflict } \\
\text { resolution }\end{array}$ & Landowner & $\begin{array}{l}\text { Promote sustainable water management and discussions through gameplay for } \\
\text { which each player is responsible for providing enough clean water to his } \\
\text { family. }\end{array}$ \\
\hline 2008 & Catchment Detox & $\begin{array}{l}\text { hcatchmentdetox.net.a } \\
\text { u/home/ }\end{array}$ & $\begin{array}{l}\text { Ecosystem ecology, } \\
\text { watershed management, } \\
\text { planning }\end{array}$ & Planner & $\begin{array}{l}\text { To create a thriving and environmentally healthy catchment by managing } \\
\text { agriculture, forestry, industry, tourism and ecosystem activities. }\end{array}$ \\
\hline 2009 & $\begin{array}{l}\text { Globalization of } \\
\text { Water Role-Play }\end{array}$ & $\begin{array}{l}\text { utwente.nl/water/resea } \\
\text { rch/games } \\
\text { Hoekstra (2012) }\end{array}$ & $\begin{array}{l}\text { Globalization, water } \\
\text { management }\end{array}$ & $\begin{array}{l}\text { Head of State, Minister of } \\
\text { Environment and } \\
\text { Agriculture, Minister of } \\
\text { Trade and Foreign Affairs }\end{array}$ & $\begin{array}{l}\text { To convey the message that wise water resources management is not simply a } \\
\text { national matter, but to be understood in a global context. }\end{array}$ \\
\hline 2010 & $\begin{array}{l}\text { Sustainable Delta } \\
\text { Game }\end{array}$ & $\begin{array}{l}\text { http://www.delta- } \\
\text { alliance.org/toolboxov } \\
\text { erview/sustainabledelt } \\
\text { agameHaasnoot et al. } \\
(2010) \\
\end{array}$ & $\begin{array}{l}\text { Water management, policy } \\
\text { making, conflict resolution }\end{array}$ & Planner & $\begin{array}{l}\text { To help players learn about the challenges of water management in an } \\
\text { uncertain future through the development of sustainable water management } \\
\text { plan for a river delta. }\end{array}$ \\
\hline \multirow{3}{*}{2011} & River Basin Game & $\begin{array}{l}\text { utwente.nl/water/resea } \\
\text { rch/games } \\
\text { Hoekstra (2012) }\end{array}$ & $\begin{array}{l}\text { Irrigation, water management, } \\
\text { common-pool resources, } \\
\text { conflict resolution }\end{array}$ & Farmer & $\begin{array}{l}\text { Players controlling different sections of a river basin and try to maximize } \\
\text { benefits of farming. Promotes understanding of a catchment, factors } \\
\text { controlling access to water and conflict dynamics. }\end{array}$ \\
\hline & $\begin{array}{l}\text { LIBRA River Basin } \\
\text { Simulation Game }\end{array}$ & Rusca et al. (2012) & River basin planning & $\begin{array}{l}\text { River basin authority, city } \\
\text { water supply utility, } \\
\text { irrigation district }\end{array}$ & $\begin{array}{l}\text { To give participants insight into the multi-disciplinary character of integrated } \\
\text { water resources management, with a strong focus on water demand } \\
\text { management. }\end{array}$ \\
\hline & Fate of the World & fateoftheworld.net & Climate change & International policy maker & $\begin{array}{l}\text { Play through different missions involving sociopolitical events, energy } \\
\text { consumption, population growth, natural disasters, etc. and make decisions } \\
\text { with the goal of improving global climate change patterns. }\end{array}$ \\
\hline \multirow{4}{*}{2012} & Irrigania & $\begin{array}{l}\text { irrigania.ch/ } \\
\text { Seibert and Vis (2012) }\end{array}$ & $\begin{array}{l}\text { Irrigation, water management, } \\
\text { common-pool resources, } \\
\text { conflict resolution }\end{array}$ & Farmer & $\begin{array}{l}\text { Utilize shared surface and ground water resources within a village of other } \\
\text { farmers to irrigate crops and become the most profitable farmer. }\end{array}$ \\
\hline & Aqua Republica & aquarepublica.com/ & $\begin{array}{l}\text { Integrated water resource } \\
\text { management, conflict } \\
\text { resolution }\end{array}$ & City planner & $\begin{array}{l}\text { To promote sustainable water resource management through experience gained } \\
\text { by making decisions to manage a catchment in real life scenarios. }\end{array}$ \\
\hline & Citizen Science & $\begin{array}{l}\text { filamentgames.com/pr } \\
\text { ojects/citizen-science } \\
\text { Gaydos and Squire } \\
\text { (2012) }\end{array}$ & Lake ecology & Citizen scientist & $\begin{array}{l}\text { To encourage players' active participation in society by providing the } \\
\text { perspective that they are capable sources of legitimate science-driven } \\
\text { community activism through the narrative of a citizen concerned about the } \\
\text { health of a local lake. }\end{array}$ \\
\hline & Hydromonopoly & $\begin{array}{l}\text { thewaterchannel.tv/en/ } \\
\text { videos/categories/view } \\
\text { video/1275/events/jord } \\
\text { an-river-basin-game }\end{array}$ & $\begin{array}{l}\text { Water management, conflict } \\
\text { resolution }\end{array}$ & Government decision maker & $\begin{array}{l}\text { To promote dialogue between players and understanding of concepts related to } \\
\text { sustainability and resource management within the Jordan River Basin. }\end{array}$ \\
\hline 2013 & $\begin{array}{l}\text { Climate Change } \\
\text { Survivor }\end{array}$ & $\begin{array}{l}\text { pacinst.org/reports/cli } \\
\text { mate_change_survivor } \\
\text { _game/ }\end{array}$ & Climate Change & Yourself & $\begin{array}{l}\text { To promote awareness of the actions that can be taken to prepare and protect } \\
\text { ourselves from the impacts of climate change and discuss factors that make us } \\
\text { more or less safe in regard to climate change. }\end{array}$ \\
\hline
\end{tabular}


Table 2. Additional information on the reviewed environmental management games.

\begin{tabular}{|c|c|c|c|c|c|}
\hline Game & $\begin{array}{l}\text { Number of } \\
\text { Players }\end{array}$ & Participants & Type & $\begin{array}{l}\text { Computer } \\
\text { Graphics }\end{array}$ & Availability \\
\hline Irrigation Management Game & $10-26$ & $\begin{array}{l}\text { Students, } \\
\text { professionals }\end{array}$ & Hybrid simulation game & $2 \mathrm{D}$ & $\begin{array}{l}\text { Directions } \\
\text { given }\end{array}$ \\
\hline Geology Explorer & Multiple & Students & Online digital game & $2 \mathrm{D}$ & Free online \\
\hline Build a Prairie & 1 & Students & Online digital game & $2 \mathrm{D}$ & Free online \\
\hline $\begin{array}{l}\text { Learning Sustainable } \\
\text { Development Game }\end{array}$ & $4-6$ & Students & Card game & N/A & Not explained \\
\hline Samba Role Play & Multiple & Stakeholders & Board game & N/A & Not explained \\
\hline The Great Green Web Game & 1 & $\begin{array}{l}\text { Students, } \\
\text { stakeholders }\end{array}$ & Online digital game & $2 \mathrm{D}$ & Free online \\
\hline $\begin{array}{c}\text { Industrial Chlorine Transport } \\
\text { Metagame }\end{array}$ & Multiple & $\begin{array}{l}\text { Students, } \\
\text { professionals }\end{array}$ & Card game & N/A & Not explained \\
\hline Slyvopast & $2-4$ & Students & Hybrid simulation game & $2 \mathrm{D}$ & Not explained \\
\hline River basin game & Multiple & $\begin{array}{l}\text { Students, } \\
\text { professionals, } \\
\text { stakeholders }\end{array}$ & Board game & $\mathrm{N} / \mathrm{A}$ & $\begin{array}{l}\text { Directions } \\
\text { given }\end{array}$ \\
\hline Industrial Waste Game & $5-6$ & Students & Card game & N/A & $\begin{array}{l}\text { Directions } \\
\text { given }\end{array}$ \\
\hline Shrub Battle & 4 & Students & Board game & N/A & Not explained \\
\hline Climate Challenge & 1 & General public & Online digital game & $2 \mathrm{D}$ & Free online \\
\hline Butorstar & $8-10$ & Students & Hybrid simulation game & $2 \mathrm{D}$ & Not explained \\
\hline Atoll Game & 8 & Stakeholders & Hybrid simulation game & $2 \mathrm{D}$ & Not explained \\
\hline Catchment Detox & 1 & General public & Online digital game & $2 \mathrm{D}$ & Free online \\
\hline $\begin{array}{c}\text { Globalization of Water Role Play } \\
\text { Game }\end{array}$ & 12 & Students & $\begin{array}{c}\text { Computer assisted board } \\
\text { game }\end{array}$ & $2 \mathrm{D}$ & Free online \\
\hline Sustainable Delta Game & Multiple & $\begin{array}{l}\text { Students, } \\
\text { professionals, } \\
\text { stakeholders }\end{array}$ & $\begin{array}{l}\text { Hybrid simulation game } \\
\text { (online digital game in } \\
\text { development) }\end{array}$ & $3 \mathrm{D}$ & Contact given \\
\hline River basin game & $9-15$ & Students & Computer assisted game & $2 \mathrm{D}$ & Free online \\
\hline $\begin{array}{l}\text { LIBRA river basin simulation } \\
\text { game }\end{array}$ & Multiple & Professionals & Hybrid simulation game & $2 \mathrm{D}$ & Not explained \\
\hline Fate of the World & 1 & General public & Digital Game & $3 \mathrm{D}$ & $\begin{array}{l}\text { Purchase } \\
\text { online }\end{array}$ \\
\hline Irrigania & $3-6$ & Students & Online digital game & $2 \mathrm{D}$ & Free online \\
\hline Aqua Republica & Multiple & Students & Online digital game & $3 \mathrm{D}$ & Free online \\
\hline Citizen Science & 1 & Students & Online digital game & $2 \mathrm{D}$ & Not explained \\
\hline Hydromonopoly & 5 & $\begin{array}{l}\text { Students, } \\
\text { stakeholders }\end{array}$ & Board game & N/A & Contact given \\
\hline Climate Change Survivor & $3-6$ & General public & Board game & N/A & $\begin{array}{l}\text { Directions } \\
\text { given }\end{array}$ \\
\hline
\end{tabular}


List of Figures

Fig.1 Environmental management games over time

Fig.2 Environmental management game topics in the compiled sample

Fig.3 Type of serious environmental management games over time 


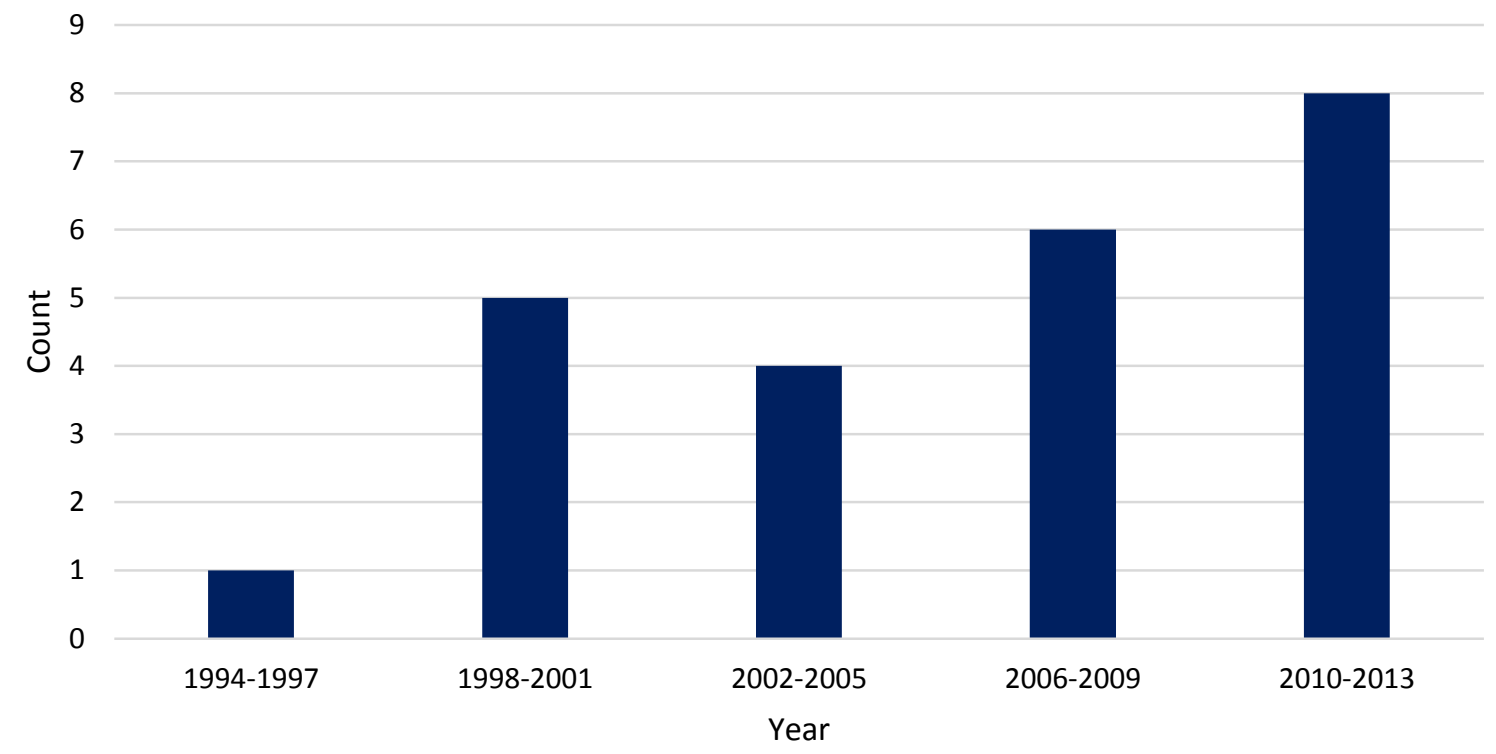

Fig.1 Environmental management games over time 


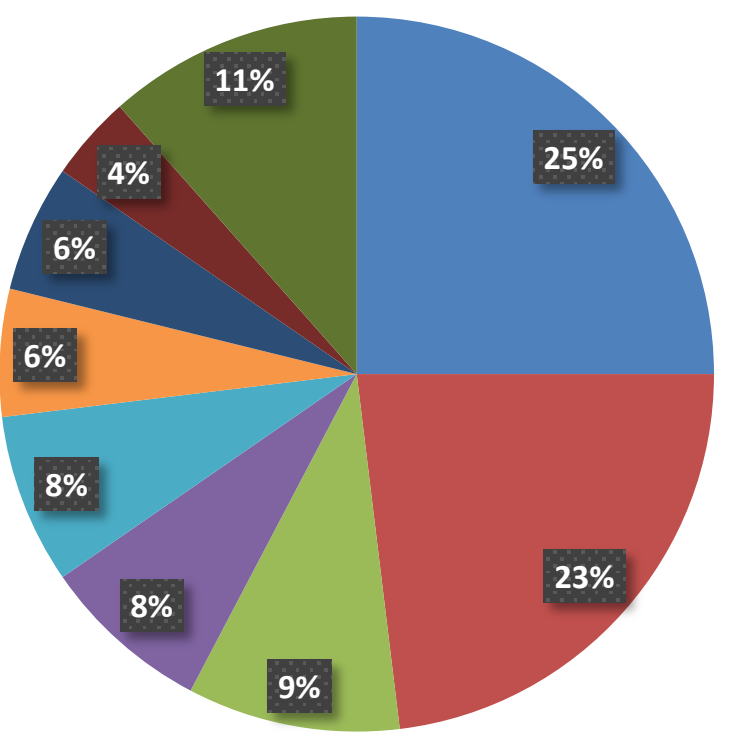

\author{
- Conflict Resolution \\ water Management \\ - Irrigation \\ Ecosystem Ecology \\ Environmental Education \\ - Common-Pool Resources \\ - Natural Resource Management \\ - Climate Change \\ - Other
}

Fig.2 Environmental management game topics in the compiled sample 


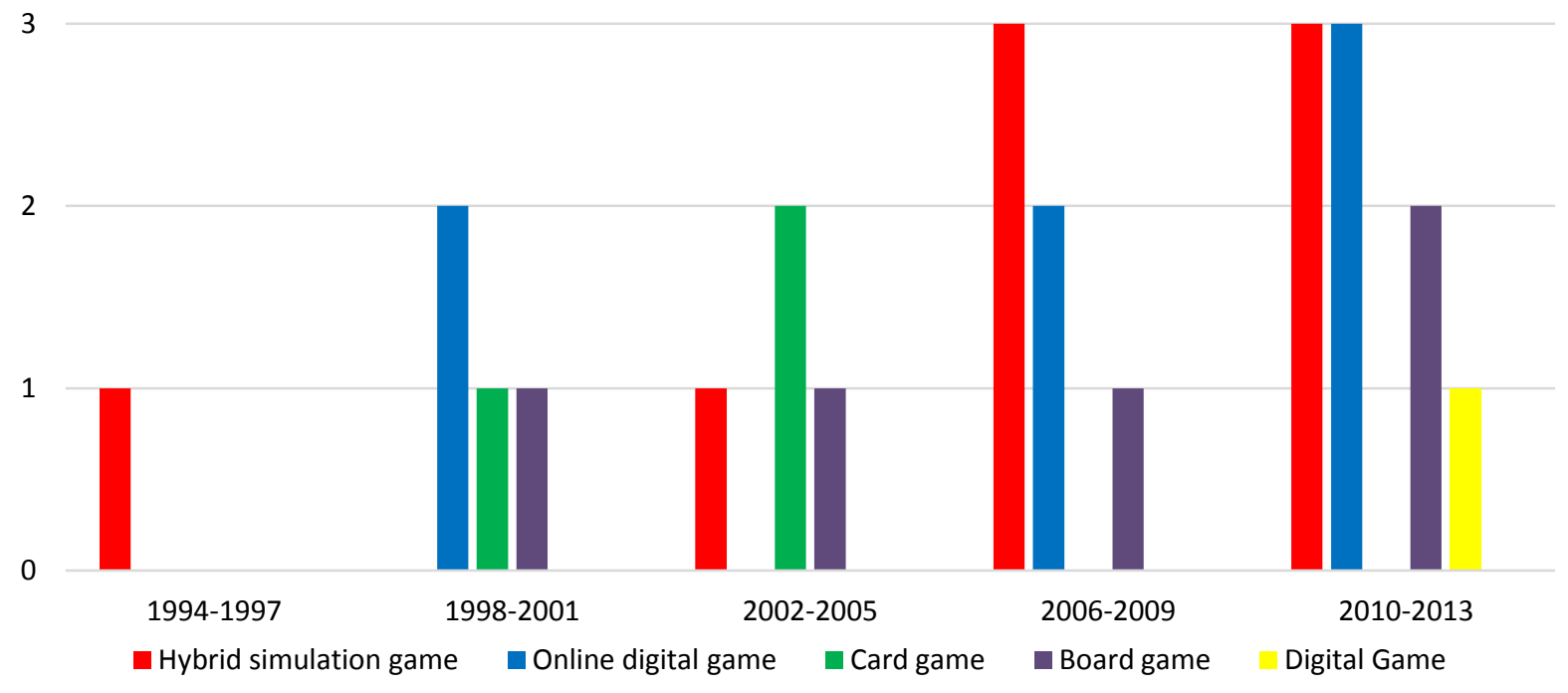

Fig.3 Type of serious environmental management games over time 